\title{
Radioprotective properties of Sophora extrac
}

\author{
Sevil Akif Mamedli \\ Institute of Radiation Problems of the Azerbaijan NAS, 31a, H. Javid Ave., Baku, Azerbaijan
}

Email address:

mamedli.sevil@gmail.com, azeri_wom@yahoo.com

To cite this article:

Sevil Akif Mamedli. Radioprotective Properties of Sophora Extrac. European Journal of Biophysics. Vol. 2, No. 3, 2014 , pp. $13-16$. doi: 10.11648/j.ejb.20140203.11

\begin{abstract}
A research on radioprotective activity of an extract of Sophora - Sophora japonica L. was carried out at sharp gamma irradiation of seeds of tobacco and wheat. Preliminary treatment of seeds with these preparations resulted in stabilization of the maintenance of pigments of chlorophylls and carotinoids at sprouts of wheat and to decrease in number of chromosomal aberrations in apical meristem of sprouts of tobacco - Nicotiana tabacum L. obtained from the irradiated seeds.
\end{abstract}

Keywords: Wheat, Tobacco Nicotiana Tabacum L., an Extract of Sophora Japonica L., Seeds, Ionizing Radiation, Pigments, Chromosomal Aberrations (chrA)

\section{Introduction}

In connection with increase of the maintenance of pollutants of anthropogenic origin with a wide action spectrum in particular radionuclide pollution in an environment, actual problem is searching of effective preparations of the natural origin capable to have protective effect on cells' genome. Considerable interest to genome protection problem is connected at least with two principal causes: necessity development of approaches to protection of cells and organisms from mutagens of the environment and possibility for the majority of protectors to be effective not only against processes of induced mutagenesis but also against carcinogenesis. Antimutagen preparations of a biological origin have got advantages before chemical ones as they can be easily obtained from different plants, wastages, quickly checking up their action on plant and animal test objects [1]. A significant number of data about antimutagen effect of crude extracts of many plants contain in literature [1-3]. Except of antimutagen action, significant interest represents immune stimulating and adaptogenic properties of plant preparations particularly preparations from walnut Juglans regia L. [4].

Plant test systems are used as genetic test systems for screening and monitoring of pollution of the environment for revealing and quantitative evaluation influence of factors with genotoxic effect and their applications is recommended by the World Organization of Public Health $[5,6]$. Plants can activate non-mutagenic compounds (promutagens) with formation of active mutagens that makes plant test systems analogue of test systems on the basis of mammal cells. In this connection the data received on plant objects are acceptable or even more acceptable for extrapolation to the person than the data received with application of such biological test systems as a bacterium, drosophila and yeast. Leaded calculation of plural correlation has shown a high level of dependence of congenital defects of development from quantity of chromosomal aberrations in epithelial cells of a tunica mucosa of mouth at children and chromosomal aberrations at the plants which have been brought up on water samples which is used by the population [1]. Furthermore application of plants for testing substances with antimutagen and radioprotector properties is represented perspective.

The purpose of the given research was studying radioprotector properties of an extract of Sophora Sophora japonica $L$. by means of analysis of biochemical and cytogenetic parameters of plants at an irradiation and at influence of the given preparation.

\section{Materials and Methods of Research}

Protective action of an extract of Sophora has been studied by means of biochemical definition content of pigments of chlorophylls and carotinoids at wheat variety of "Qirmizi bugda" and also with use of a method of cytogenetic evaluation of number of chromosomal 
aberrations (chrA) in cells root meristems of tobacco Nicotiana tabacum $L$.

Irradiation of seeds of plants carried out on installation "Ruxund 20000" $\left({ }^{60} \mathrm{Co}\right)$ at doze rate of radiation $0,5-1$ Gy/min.). In experimental variants seeds of wheat and tobacco before exposure to radiation preliminarily processed during 15 hours in the extract of Sophora (Sophora japonica L.) bringing in $6 \mathrm{ml}$ of the given solution into a variant in the control used distilled water. Control and irradiated seeds sprouted on a humid filtering paper in Petri dishes at $30-32{ }^{\circ} \mathrm{C}$ for tobacco and $24-28{ }^{\circ} \mathrm{C}$ for wheat.

For definition quantity of chrA at tobacco in appearance of primary rootlet in the length of 1,5-2,5 cm they fixed in mixture of Carnoy (ethyl alcohol: glacial acetic acid in proportion of $3: 1$ ) in 24 hours transferred to $80 \%$ ethyl alcohol. Coloration made by acetoorcein [2]. Temporary and permanent preparations have been prepared. A number of aberrant anaphases and defined number of chromosomal aberrations (chrA) on cytological preparations have been counted up in cells. At application of anaphase method formed bridges, chromosomal fragments, lagging chromosomes and other damages were counted up. In each variant 100 anaphases and early telophases, not sharing chromosomal aberrations on separate categories as it is recommended in $[7,8]$ have been analyzed. Frequency of aberrant anaphases expressed in percentage of the overlooked corresponding phases of mitosis (200 per each variant). Quantification contents of chlorophylls both a and $b$ and carotinoids of wheat carried out by spectrophotometric method using $80 \%$ of acetone $[1,9,10]$.

Statistical analysis of the data is carried out by application of nonparametric methods - rank test of Wilkinson-Mann-Witney, a method of signs and rank test of Wilkinson. Statistical analysis of the qualitative data is carried out by application of $\chi^{2}$ criterion (chi-square) of Pirsaon. In cases of when the number of the data even in one group was less than five results checked by Fisher's exact method. In application of these methods for statistical treatment has been used computer programs EXCEL 2003 and S-PLUS 2000.

\section{Results and Discussion}

Influence of the extract of Sophora on the content of pigments on wheat. A high sensitivity of the pigmentary apparatus of plants to effect of various stressors is known. For example, at processing the higher water plants by salts of heavy metals change of content and proportion of different pigments were marked for the first day of observation even at the minimal investigated concentration $(0,5 \mathrm{ml}$ maximum permissible concentration) when did not develop yet necrotic damages of tissues and there was no stunt [3]. Stress factors cause changes proportion of chlorophylls $\mathrm{a} / \mathrm{b}$. Higher plants in which photosynthesis occurs in normal conditions, contain a great quantity of chlorophyll a than chlorophyll b, i.e. the proportion of chlorophylls $\mathrm{a} / \mathrm{b}$ is normally more than 1 . Decreasing the mentioned proportion to a level less than 1 testifies about shift in photosynthetic system and indicated prevalence processes of destruction of organic substances above their synthesis.

In our experiments the irradiation decreased in the general content of pigments. Previous processing of seeds before irradiation by the extract of Sophora decreased reduction of concentration of chlorophyll a in plant tissues caused by effect of irradiation and stabilized concentration of chlorophyll b [Tab.1]. At the same time the given effect was even more expressed at rising doze of irradiation. For example, at the doze of irradiation 10Gy the content of chlorophyll a in a variant processed by the extract of Sophora, was approximately 1,2 times higher than in a variant irradiated without processing. The same tendency was kept in high dozes of irradiation of seeds [Tab. 2 ].

Simultaneously with decreasing contents of chlorophyll a at wheat received from the irradiated seeds, content of carotinoids decreased, but their relative quantity in relation to chlorophylls grew [Tab.1 and 2]. Processing by the extract of Sophora in the certain degree decreased radiation-induced reduction content of carotinoids in plant tissues [Tab. 1 and 2]. Increasing content of carotinoids at stress loads consider as the protective mechanism prevent from destruction and peroxide oxidation of chlorophylls [5, $1]$.

Carotinoids are the major antioxidants of natural lipid which protect the cell from effect of singlet oxygen. Antioxidant properties of carotinoids depend on their structure, a degree of affinity to cellular phospholipids and lipoproteids, from localization molecules of carotinoids in membrane and their surroundings and also from partial pressure of oxygen [4]. Carotinoids are predecessors of vitamin A and, also possessing powerful antioxidant effect. Thus the extract of Sophora showed stabilizing influence on the content of photosynthetic pigments at plants.

Influence of the extract of Sophora on a level of radiating-induced chromosomal aberrations at plant of tobacco. Preliminary processing by the extract of Sophora seeds of tobacco up to the irradiation authentically decreased quantity of radiating-induced chrA in root meristems of sprouts [Tab.3]. In particular at dozes of irradiation 5 and $15 \mathrm{~Gy}$ quantity of chrA decreased approximately in 1,5 times.

The samples untreated by the Sophora extract showed a growth in the level with increased radiation exposure, whereas the level in the treated samples remained stable at up to $10 \mathrm{~Gy}$ and began increasing only after the radiation dose reached $15 \mathrm{~Gy}$.

Several studies of the genetic traits of DNA repair were carried out using physical methods. We consider this approach promissory as it allows us to characterize not only the damage and repair of the primary DNA structure, but also the restoration of its conformation, which is essential for normal functioning of DNA.

Therefore the simulation experiments conducted are 
another evidence showing that the radioprotective effect of the Sophora extract is highly versatile, manifesting itself in the regulation of mutagenesis. According to the generally accepted definition, antimutagens are medications that can - along with the impact on the formation of induced genetic damage - adjust the frequency of spontaneous mutations.

The undisputed practical value of the Sophora extract is emphasized by its ability to inhibit mutagenesis induced by prolonged exposure to low doses of ionizing radiation and the accompanying influence of their mutagenic factors of different nature in acute doses. The importance of the Sophora extract's antimutagenic effect in these conditions results from the fact that many environmental mutagens, including ionizing radiation, cause chronic low-dose radiation exposure of natural populations.

A comparative study of the effect of the Sophora extract, walnut extract and rutin showed that all these substances have strong gene protective properties and are almost similarly effective.

Thus, considering the results obtained in this paper, the natural agents which we have studied, as well as those of a synthetic origin, have radioprotective properties and show potential as a basis for the development of medications and food supplements that will be effective in case of chronic exposure to radionuclide contamination and various genotoxicants.

Thus in use as test system of root meristems of tobacco on parameter output of chrA, it is shown by us, that preliminary processing of seeds by the extract of Sophora resulted in significant decrease output of chrA at gamma irradiation that specifies presence at this preparation radioprotector and antimutagen properties.

Table 1. Influence of preprocessing by the extract of Sophora to content of chlorophylls and carotinoids at the wheat, $p<0.05$

\begin{tabular}{|c|c|c|c|c|c|c|c|}
\hline Dose, Gy & Variants & Chlorophyll a & Chlorophyll b & Chlorophyll $\mathbf{a}+\mathbf{b}$ & Chlorophyll a/b & Carotinoids & $\begin{array}{l}\text { Chlorophyll } \\
\text { a+b/carotinoids }\end{array}$ \\
\hline 0 & Control & 2.6 & 0.8 & 3.4 & 3.4 & 1.4 & 2.3 \\
\hline \multirow{2}{*}{1} & Control & 2.3 & 0.7 & 3.1 & 3.2 & 1.3 & 2.5 \\
\hline & Extract of Sophora & 2.5 & 0.8 & 3.3 & 3.2 & 1.4 & 2.4 \\
\hline \multirow{2}{*}{2.5} & Control & 2.1 & 0.7 & 2.8 & 3.2 & 1.1 & 2.5 \\
\hline & Extract of Sophora & 2.3 & 0.7 & 2.9 & 3.5 & 1.2 & 2.5 \\
\hline \multirow{2}{*}{5} & Control & 2.0 & 0.6 & 2.7 & 3.2 & 0.9 & 2.7 \\
\hline & Extract of Sophora & 2.1 & 0.6 & 2.7 & 3.4 & 1.0 & 2.8 \\
\hline \multirow{2}{*}{10} & Control & 1.8 & 0.6 & 2.4 & 3.1 & 0.8 & 2.9 \\
\hline & Extract of Sophora & 2.1 & 0.6 & 2.7 & 3.4 & 0.9 & 3.1 \\
\hline \multirow{2}{*}{15} & Control & 1.8 & 0.5 & 2.3 & 3.2 & 0.8 & 2.9 \\
\hline & Extract of Sophora & 2,0 & 0.6 & 2.6 & 3.3 & 0.9 & 2.9 \\
\hline
\end{tabular}

Table 2. Influence of preprocessing by the extract of Sophora to content of chlorophylls and carotinoids at the wheat at the high doses of irradiation, $p<0.05$

\begin{tabular}{|c|c|c|c|c|c|c|c|}
\hline Dose, Gy & Variants & Chlorophyll a & Chlorophyll b & Chlorophyll a+b & Chlorophyll a/b & Carotinoids & $\begin{array}{l}\text { Chlorophyll } \\
\text { a+b/carotinoids }\end{array}$ \\
\hline 0 & Control & 4.3 & 1.3 & 5.6 & 3.2 & 1.0 & 5.7 \\
\hline \multirow{2}{*}{200} & Control & 3.6 & 1.1 & 4.7 & 3.3 & 0.8 & 6.2 \\
\hline & Extract of Sophora & 3.9 & 1.3 & 5.2 & 3.1 & 0.9 & 5.9 \\
\hline \multirow{2}{*}{250} & Control & 3.2 & 1.0 & 4.3 & 3.1 & 0.7 & 5.9 \\
\hline & Extract of Sophora & 3.6 & 1.1 & 4.7 & 3.4 & 0.8 & 5.6 \\
\hline \multirow{2}{*}{300} & Control & 3.2 & 1.0 & 4.1 & 3.3 & 0.7 & 6.1 \\
\hline & Extract of Sophora & 3.4 & 1.0 & 4.4 & 3.4 & 0.8 & 5.4 \\
\hline
\end{tabular}

Table 3. Influence of gamma irradiation and extract of Sophora to output of chromosomal aberrations in tobacco Nicotiana tabacum

\begin{tabular}{llllll}
\hline Dose, Gy & Control (without processing) & $\mathbf{P}(\mathbf{0}$ Gy) & Extract of Sophora & P(0 Gy) & \\
\hline 0 & 3.70 & & 3.25 & $\mathrm{P}$ & $\mathrm{p}<0.01$ \\
1 & 4.38 & $\mathrm{p}<0.01$ & 3.31 & $\mathrm{p}<0.05$ & $\mathrm{p}<0.01$ \\
2.5 & 4.29 & $\mathrm{p}<0.01$ & 3.55 & $\mathrm{p}<0.01$ & $\mathrm{p}<0.01$ \\
5 & 4.98 & $\mathrm{p}<0.01$ & 3.40 & $\mathrm{p}<0.01$ & $\mathrm{p}<0.05$ \\
10 & 5.76 & $\mathrm{p}<0.01$ & 3.37 & $\mathrm{p}<0.01$ \\
15 & 7.58 & $\mathrm{p}<0.01$ & 5.21 & $\mathrm{p}<0.01 \quad$ \\
\hline
\end{tabular}

$\mathrm{P}$ - reliability difference between plant groups

\section{References}

[1] Musiyaka V.K. Antimutagen_action of preparations of natural origin // Physiology and biochemistry of cult. plants. - 2001. - V. 33, № 3. - P. 216-225.

[2] Barilyak I.R., Dugan A.M .Research of antimutagen action of spirituous extracts from culture of tissue of Rhodiola rosea and Polystias ficifolia in experiences on Salmonella typhimurium // Rep. of Ukraine AS. - 1994. - № 11. - P. 164167.

[3] Agabeyli R.A., Gasimova T.E., Alekberov U.K. Antimutagen activity of plant extracts from Armoracia rusticana, Ficus carica, Zea mays and peroxidases in cells of eukaryotes // Cytology and genetics. - 2004. - № 2. - P. 40-45. 
[4] Abdullayev A.S., Farajov M.F., Azizov I.V. Oil of a walnut as immunostimulating and radioprotective means from action of various factors of natural-technogenic origins // Safety problem of nuclear power plants and Chernobyl. - 2005. Issue. 3. Part. 1. - P. 167-171.

[5] Grant W.F. The present status of higher plant bioassays for the detection of environmental mutagens // Mutat. Res. 1994. - № 310. - P. 175-185.

[6] Grant W.F. Higher plant assays for the detection of chromosomal aberrations and gene mutations - a brief historical background on their use for screening and monitoring environmental chemicals // Mutat. Res. - 1999. № 426. - P. 107-112.

[7] Rank J., Nielsen M.H. A modified Allium test as a tool in the screening of the genotoxicity of complex mixtures // Hereditias. - 1993. - № 118. - P. 49-53.
[8] Rank J., Jensen A.G., Skov B., Pedersen L.H., Jensen K. Genotoxicity testing of the herbicide Roundup and its active ingredient glyphosate isopropylamine using the mouse bone marrow micronucleus test, Salmonella mutagenicity test, and Allium anaphase-telophase test // Mutat. Res. - 1993. № 300. - P. 29-36.

[9] Гродзинський Д. М. Парадигми сучасної радіобіології // Проблеми безпеки атомних електростанцій і Чорнобиля. - 2005. - Вип. 3. Ч. 2. - С. 9-16.

[10] Мамедли С.А., Гродзинский Д.М. Роль типа опыления в проявлении радиационно- индуцированной нестабильности генома у растений.//Доп. НАНУ-№ 7.2007.-C.165-170. 